$1-1-1982$

\title{
Judicial Style in Californias Federal Admiralty Court: Ogden Hoffman and the First Ten Years, 1851-1891'
}

Christian G. Fritz

University of New Mexico - School of Law

Follow this and additional works at: https://digitalrepository.unm.edu/law_facultyscholarship

Part of the Law Commons

\section{Recommended Citation}

Christian G. Fritz, Judicial Style in Californias Federal Admiralty Court: Ogden Hoffman and the First Ten Years, 1851-1891', 64 Historical Society of Southern California 125 (1982).

Available at: https://digitalrepository.unm.edu/law_facultyscholarship/108

This Article is brought to you for free and open access by the UNM School of Law at UNM Digital Repository. It has been accepted for inclusion in Faculty Scholarship by an authorized administrator of UNM Digital Repository. For more information, please contact amywinter@unm.edu, Isloane@salud.unm.edu, sarahrk@unm.edu.

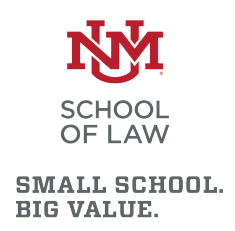

BIG VALUE. 


\title{
Judicial Style in California's Federal Admiralty Court: Ogden Hoffman and the First Ten Years, 1851-1861
}

\author{
BY CHRISTIAN G. FRITZ
}

COMPLIMENTS OF THE UNITED STATES DISTRICT COURT FOR THE NORTHERN DISTRICT

OF CALIFORNIA HISTORICAL SOCIETY

A reprint of the Southern California Quarterly

Fall 1982, Vol. LXIV, No. 3 


\title{
Judicial Style in California's Federal Admiralty Court: Ogden Hoffman and the First Ten Years, 1851-1861
}

\author{
BY CHRISTIAN G. FRITZ
}

The admiralty jurisdiction of California's federal district court in San Francisco provides insight into how one federal judge understood and executed his role in a frontier setting. How the Northern District of California's first judge conducted his court, exercised his jurisdiction, arrived at his conclusions, and fashioned his opinions - what might be considered his judicial style reveals much about legal'practice and judicial process in the far west at the middle of the nineteenth century.' An examination of the first decade of federal admiralty cases in California suggests that law on the frontier entailed much learning, complexity and legal sophistication.

Ogden Hoffman, the Northern District's first judge, was born in New York City on October 16,1822, a descendant of an old New York Dutch family. ${ }^{2}$ His father, Ogden Hoffman, Sr., was a leader of the New York bar and a nationally known member of the Whig party. Like his father, Hoffman, Jr., attended Columbia University before turning to law. After reading law in the office of Mark Silbey of Canandaigua, New York, Hoffman entered Dane Hall (Harvard Law School) on October 19, 1840 to study under its two eminent professors: Joseph Story and Simon Greenleaf. In 1842 he left with his L.L.M. and read more law in the office of Benjamin D. Silliman of New York City, before being admitted to the bar.

Instead of settling down to a practice, Hoffman, Jr., traveled extensively in Europe, spending much time in Paris where "he acquired a good knowledge of the French tongue." Upon his return to New York he practiced law under his father's eye but aiso thoroughly enjoyed the "life of a society man."4 In 1850 Hoffman, Jr., booked passage for California to seek his fortune.

Before Hoffman's arrival in San Francisco in May of 1850, his 


\section{Historical Society of Southern California}

father tried to secure him a political post. When the appointment did not come IIoffman began to practice law. New York connections brought him some business but not enough to prosper. A friend later recalled that Hoffman "was not fitted . . . for the rough and tumble life of a frontier bar." Yet Hoffman retained an optimism and self-confidence bragging in letters home that he had "little doubt that before long I shall be realizing a hasdsome sum by my practice." Inflation eroded what little he earned, but he consoled himself "by the reflection that I have made something." "

Hoffman sorely missed New York society, and the euphoric spirit of frontier California did not lessen his longing. He harbored few romantic illusions about the Gold Rush, perhaps because he had failed to strike it rich himself. "A system of deception is practiced here by various persons connected with the press of which the effect if not the design is to beget the most exaggerated ideas of the chances and fortunes that await the immigrant. The papers teem with accounts sometimes true of large lumps being discovered but they contain no mention of the thousands who are toiling day after day without results or wasting their time and strength in useless 'prospecting." "' Noting an imbalance between the vast capital and manpower pouring into California and the value of gold exported, Hoffman concluded that California "has been and will be a source of loss to the world and especially to the U.S. and so far as we can yet see we would have been richer without her than with her." Surely some of Hoffman's disillusionment dissipated with the news of his appointment by President Millard Fillmore on February 1, 1851, as. United States Judge for the Northern District of California - less than three months after his 29th birthday. ${ }^{10}$

Four crowded dockets faced the young, new judge: admiralty, "common law, equity, crimes, and land." While the adjudication of land cases captured the public imagination in the early years and required an enormous amount of attention, the other three dockets also presented an abundant source of work. In fact, during the first decade of the court's existence, Hoffman wrote over 150 opinions in admiralty alone."

Initially most striking in Hoffman's early admiralty cases are the sources he relied on in reaching his decisions. Despite the 


\section{California’s Federal Admiralty Court}

international basis of the law of the sea, one might have expected a mid-nineteenth-century admiralty court in California to place substantial reliance upon American or English sources and less upon European Continental sources. Hoffman's opinions attain a striking degree of sophistication in his citation and discussion of Continental - especially French - statutes, cases, and treatises. $^{22}$

Hoffman frequently referred to two eighteenth-century French treatises: Balthazard Marie Émérigon's work on maritime loans (translated in English in 1811 by John E. Hall) and Pierre Sébastien Boulay-Paty's four volume classic Cours de droit commercial maritime, d'après les principles et suivant l'ordre du Code de Commerce (along with commentaries on the code by René Josué Valin and Joseph Adrien Rogron). The judge also relied heavily upon the major Italian compilation on maritime law, the Consulate of the Sea or Il Consulato del mare, nel quale si comprendono tutti gli statuti, o ordini, disposti da gli antichi per ogni cosa di mercantia, of di navigare, which Hoffman sometimes cited in a French translation (probably P. B. Boucher's 1808 edition).

Other French authorities who occasionally found their way into Hoffman's opinions included Etienne Cleirac, Jean Domat, Robert Joseph Pothier (whose treatise on the law of obligations Hoffman might have used in any one of three translations into English by William David Evans), and Jean Marie Pardessus's Collection de lois maritimes antérieures au XVIII siecle.

It would be wrong to conclude that every citation to French sources resulted from independent research in those sources, for it is evident that Hoffman occasionally drew upon the analysis of French authorities found in other American writings and decisions. Nonetheless, Hoffman did read French, and his use of French authorities strongly suggests that he owned or at least had access to many of the sources he cited. While Hoffman developed a reputation as a linguist, his demonstrated command of foreign languages in his early opinions was limited to French and Latin.

The wide variety of American and English case law and treatises employed by Hoffman from the earliest date is also surprising for a frontier court. ${ }^{13}$ In 1851 alone Hoffman cited a large number of English reporters including cases from Common Pleas 


\section{Historical Society of Southern California}

in Bingham's New Cases, Taunton's Reports, and Broderip \& Bingham's Reports; from Exchequer in Price's Reports and Meeson \& Welsby's Reports; from King's Bench in East's Reports, Blackstone's Reports, and Cowper's Reports; from Admiralty in Dodson's Reports, William Tarn Pritchard's Admiralty Digest, Edward's Reports and Burrell's Admiralty Cases; and from Nisi Prius in Moody \& Malkin's Reports, Buller's Reports, Carrington \& Payne's Reports, and the Nisi Prius Reports. In addition to such reporters Hoffman relied heavily on Charles Abbott (1st Baron Tenterden's) A treatise of the law relative to merchant ships and seamen (possibly using the 5th American edition with notes by Joseph Story).

Hoffman drew upon an impressive range of American materials during his first year on the bench including Opinions of the United States Attorney General, Reports of the United States Supreme Court, and reports of various Circuit courts (including Sumner's Reports, Story's Reports, Mason's Reports, Wallace's Reports, Paine's Reports, Gallison's Reports, and Woodbury \& Minot's Reports). District court opinions were available through Ware's Reports, Peter's Admiralty Decisions, and Bee's Admiralty Reports. State reports wene less used but included New York (Wendell's Reports, Cowen's Reports, and Denio's Reports), Massachusetts (Pickering's Reports), and Pennsylvania (Sergeant \& Rawle's Reports, Binney's Reports, and Watts \& Sergeant's Reports). American treatises included Erastus Cornelius Benedict's The American admiralty; its jurisdiction and practice, with practical forms and directions (a work still in use today), Alfred Conkling's admiralty treatise, and Kent's Commentaries.

Ultimately, his former law professor and famous judge, Joseph Story, proved the strongest and most enduring influence on Hoffman. ${ }^{14}$ Hoffman used his teacher as a touchstone for virtually every decision that went beyond the mere weighing of factual evidence. The young judge relied heavily on Story's well-known commentaries, and particularly those on Agency, Equity, Bailments, Conflicts, and Partnership, as well as on Story's judicial opinions.

Early in 1852, Hoffman decided Wilson v. Pierce, a case that reveals his attitude toward Story. ${ }^{15}$ The case arose from rather curious circumstances. At the height of the Gold Rush, the libel- 


\section{California’s Federal Admiralty Court}

lant - a severely rheumatic resident of New York - resolved to move to Hawaii for his health. Allen T. Wilson felt forced "to leave a prosperous, growing and lucrative business, country home and friends" by New York's "harsh and rigorous climate which day by day was wearing out" his life. ${ }^{16}$ Wilson and his wife booked passage on a ship that was to sail directly for Honolulu from Boston on January 25, 1849. He had wished to avoid San Francisco (the port to which almost all other ships were sailing) not only because of its fog and inflationary prices but also "on account of the turbulent and unsettled State of the Country and the wild and raving population resorting there from all parts of the Earth." "17 At the last minute, the captain of the vessel refused to transport Wilson, his wife or Wilson's pianoforte. As a consequence Wilson did travel first to San Francisco where he fell ill - from dysentery as well as other ailments - but eventually recovered and proceeded to Hawaii.

Feeling well enough to return to San Francisco, Wilson sued Pierce (the captain who had snubbed him) for breach of contract and asked a total of $\$ 40,730$ for medical expenses, loss of earnings, and pain and suffering. Although Pierce was not in California, others had "monies, credits and effects" of the defendant which the U.S. Marshall attached as an initial step in the proceedings. ${ }^{18}$ Essentially, Wilson sought a judgment in personam (that is, where jurisdiction is based on a person rather than on property) from a federal admiralty court where the defendant was neither present in nor an inhabitant of the district where the libel was filed.

Pierce's attorney filed exceptions to the libel on the grounds that as Pierce was domiciled in Massachusetts and not within the Northern District, Hoffman had no jurisdiction. Hoffman agreed and rested his decision on the belief that such an assumption of jurisdiction would violate section 11 of the Judiciary Act of $1789,{ }^{19}$ which he interpreted as equally applicable to federal courts sitting in admiralty as in equity and common law.

In an elaborate opinion, Hoffman examined the case law and legal authorities and found a Story decision that asserted jurisdiction for District courts in admiralty over absent defendants. Although Story's statements seemed "decisive of the present question," closer examination forced him to disagree with Story's conclusion. ${ }^{20}$ Hoffman explained that the length of his opinion 


\section{Historical Society of Southern California}

not only reflected the importance of the question but "the great name of the illustrious judge, some of whose observations I have felt obliged to receive with some qualifications." ${ }^{21}$

Having labored to demonstrate the validity of his position Hoffman felt obligated to note that "In differing from a casual observation of Judge Story, I may well feel some distrust of the accuracy of my own conclusions." ${ }^{22}$ The response proved typical; while he usually deferred to Story, Hoffman would deviate if circumstances or his own analysis dictated, but then only with a self-deprecating humility.

The fact that Hoffman's conclusion called into question a general practice in federal admiralty courts added to the thrill of challenging his mentor. While Hoffman's interpretation was plausible, the weight of case law went the other way. In 1873 the United States Supneme Court expressly overruled his position, holding that federal district courts sitting in admiralty could proceed in personam against nonresident defendants by attachment of the property of such a person found within the district. ${ }^{23}$

Several reasons seem to account for the variety of sources cited by Hoffman. The most obvious and logical explanation for Hoffman's early citations inhered in the nature of a frontier judicial system - a dearth of applicable case law. Until Hoffman or other California courts generated a series of decisions, he would of necessity have to look elsewhere for guidance. The shift away from out-of-state decisions thus depended on the development of a local case law. ${ }^{4}$ During the first decade in admiralty hints of such a trend appeared in the growing frequency with which Hoffman cited his own decisions or those of California state courts. ${ }^{25}$

Another reason for the number and particularly the variety of Hoffman's citations is linked to his effort to gain the respect of the local bar. No one doubted the importance of the Northern District judgeship to the new state. But who, Californians wondered, was this young and untried man? Hoffman set out to win his spurs as California's federal judge in two ways: first, by demonstrating his diligence (by overwork that led to physical collapse by 1855) and secondly, by displaying his erudition (by offering exhaustive analyses which showed off his learning and research). 


\section{California's Federal Admiralty Court}

In pursuit of the latter objective Hoffman wrote a number of opinions that were studded with citations or contained Latin or French quotations, or used much unnecessary argument. ${ }^{26}$ In J. W. Gill v. The Schooner "Fashion," for instance, Hoffman devoted twenty-four pages to an elaborate analysis of issues and case law before dismissing the libel for lack of jurisdiction. ${ }^{27}$ In sending his father a copy of one of his earliest opinions for comment, Hoffman qualified it as "not in my judgment as good, certainly not apparently so learned as many I have written." ${ }^{28}$ Hoffman also hoped to establish his reputation as a learned judge by trying (initially unsuccessfully) to have his opinions published. ${ }^{29}$

Hoffman's opinions in the late 1850s have far fewer citations than those in the early 1850s. No doubt the pressure of judicial business precluded consistently exhaustive opinions, but by 1860 Hoffman had also dispelled any fears that he might be incompetent. Indeed, by then he had won a large measure of respect and confidence from San Francisco's legal community.

A final reason for the number of citations is related to Hoffman's effort to make a good impression. In a number of cases Hoffman's unnecessary analysis apparently stemmed from a desire not to slight the practicing bar. Out of deference and politeness to attorneys - many older than he - who made timeconsuming or impassioned arguments, Hoffman addressed their points in depth. Perhaps the citations Hoffman mustered on these occasions helped to ease the disappointment of an unfavorable decision. In any event, his conscientious response to arguments of counsel accorded with the treatment a proud, sensitive gentleman like Hoffman would have himself expected at the bar.

In large measure the respect and confidence that Hoffman earned from the legal community came from how he used legal sources and ran his courtroom. While Hoffman impressed lawyers and businessmen with his erudition, he won their support by marshaling legal authorities and case law into opinions that provided sensible compromises to conflicts.

The important business of shipping and disputes attendant with such trade provided Hoffman's first test as a judge. The common sense and awareness of business practices Hoffman displayed when allocating loss and risk among parties promoted his judicial 


\section{Historical Society of Southern California}

reputation while it enhanced the value of his tribunal to the business community. ${ }^{30}$ The practical importance of his commercial cases exceeded their numbers for they often decided such recurring questions as what notice a shipper owed to his consignee, ${ }^{31}$ what risks a shipper assumed in sending cargo around the Horn to San Francisco, ${ }^{32}$ when a carrier was entitled to freight, ${ }^{33}$ or what were the port customs with respect to general average contributions. ${ }^{34}$

One troublesome problem that Gold Rush California brought to maritime trade entailed the difficulty of holding a crew together after arrival in San Francisco. The problem arose not necessarily because of the lure of gold, but because inflation had dramatically increased the wages of seamen who shipped from San Francisco. Why should a sailor continue on a voyage working for east coast wages when he might do substantially better by shipping out from the west coast? While seamen tended to jump ship after passing through the Golden Gate, east coast shipping agents (men who procured crews for the ship's owners) sometimes resorted to chicanery in signing up sailors for voyages to but not ending in San Francisco. Maritime law prescribed clear consequences for such behavior. If a sailor abandoned a voyage before its conclusion he faced a total forfeiture of wages, but if the voyage was misrepresented to him he was not only entitled to wages but free to leave the ship. Thus the issue usually came down to a question of fact, with contradictory testimony from the master or owners and the sailors.

Initially Hoffman took a narrowly contractual view and refused to establish "the precedent that a seaman may at any time, release himself from the obligation of his contract, by procuring a messmate to swear that the voyage was misrepresented to him. ${ }^{35}$ In $185 \nsucceq$ Hoffman felt "compelled by every consideration of justice and policy, to disregard the unsupported allegation of a mariner testifying to such a fact where the means of disproving it are necessarily beyond the reach of those representing the ship."36 Hoffman continued to take a hard line and enforced forfeitures of sailor's wages in the absence of proof of misrepresentation until experience suggested that the practice of shipping agents and the circumstances of San Francisco warranted a different approach. $^{37}$ 


\section{California's Federal Admiralty Court}

In 1860 in Thomas Dooley v. The Ship "Neptune's Car" Hoffman re-examined the entire question of enforcing ship's articles. ${ }^{38}$ $\mathrm{He}$ characterized the inflation of seamen's wages in California as an almost "irresistible" temptation for sailors to desert and noted the "general custom" of the preceding years "not to insist upon the forfeiture of the whole wages, but merely on a deduction of a small sum to defray the expense of shipping other men, if the old crew are unwilling to remain on board at port wages."39 In the present case, however, the master defended a libel for a seaman's wages by claiming a forfeiture. No happier about the veracity of sailors - given "the recklessness of this class of men" - than he was in 1851, Hoffman now recognized serious defects in the shipping agent system..$^{40}$

Hoffman lamented that Congress had not regulated the shipping of sailors more closely; ideally he wanted every crew to have its articles explained by a federal officer. In the absence of such a procedure, Hoffman saw his task as devising an acceptable means of separating fraudulent from valid articles. His answer placed the burden on the master to show that the articles were fully explained to the men before a forfeiture of wages would be ordered. In other words Hoffman embraced an idea he had rejected nine years earlier under "every consideration of justice and policy." ${ }^{341}$ Hoffman's about-face was not merely inconsistent; rather it showed that he had learned from experience and how he had matured as a judge.

Hoffman reasoned that clarification of ship's articles could be more easily accomplished if the master enunciated the terms before the sailors as well as other reliable witnesses who could later be produced. Moreover, the equities demanded such a burden. "Aware, as the master is, of the strong temptation to impose on the men to which the shipping [agent], interested in filling up the crew list is subjected, and of the facility with which such impositions may be produced, especially on illiterate men; conscious too, of the rigor of the penalties he intends to enforce in case the contract be violated, such a precaution would seem to be the dictate not merely of policy but of justice." ${ }^{32}$

The effect of shifting the burden of proof from the sailors (to show misrepresentation) to the master (to show accurate representation) resulted in a decree for the libellants (the sailors 


\section{Historical Society of Southern California}

who brought the libel). The complaint of a ship owner that "the convenience of commerce" made shipping agents indispensable and that the requirement of proof thus normally remained outside the direct knowledge of the master did not move Hoffman. ${ }^{43}$ "If then shipping [agents] are and must be employed" it simply behooved masters to make sure that in the future they or other reliable witnesses were present at the signing of the articles. ${ }^{44}$

By tempering his use of legal sources with common sensical innovations that met the needs of local circumstances, Hoffman did not dispense some kind of rough frontier justice. If for no other reason, his background and learning militated against such an approach. In fact, Hoffman exerted considerable effort to buttress his decisions by case law and declared himself bound by decisions of the United States Supreme Court. ${ }^{45}$ Admittedly Hoffman's trepidation about proceeding without the guidance of case law lessened with his growing confidence as a judge, but he never lost the penchant for cases on point that marked a learned common lawyer.

Moreover, Hoffman's obedience to statutory law sometimes approached literalism. Provisions of positive law - and especially the Constitution - restricted the leeway Hoffman felt he had as a judge. ${ }^{46}$ In United States v. Hoit, Hoffman upheld the application of an 1846 federal statute dealing with bonds issued by United States collectors of ports. ${ }^{47}$ The act established time limits for the receipt of the bonds that varied depending upon whether a ship imported goods from Pacific or Atlantic ports. Literal application of the act to California imposed the shortest time period for the longest voyage and vice versa, a result Hoffman called "absurd." Nonetheless, "if in its application to California the Statute ought to be reversed it does not belong to the Court to effect the change," rather "the law making power is responsible and the remedy must be sought at its hands." ${ }^{\prime 9}$ While in this instance Hoffman showed excessive deference to statutory law, his decision resulted less from an unwillingness boldly to supply justice as he saw fit, than from a perception of the distinct roles and responsibilities of the legislature and the judiciary. Strict obedience to statute did not - as Hoffman's ultimate resolution of the ship's articles controversy showed - preclude judicial innovation. 


\section{California’s Federal Admiralty Court}

How Hoffman conducted his admiralty court also reflected an openness and common sensical approach to resolving suits before him. As an admiralty court Hoffman sat both as the finder of fact and of law. The care he took to weigh evidence and particularly his growing facility in sifting through conflicting testimony undoubtedly contributed to the esteem for his court. ${ }^{50}$

Of even greater importance - at least to the business community and those who sought the efficacy of his tribunal - was Hoffman's early and sustained commitment to look through procedural form to the substance of legal issues. ${ }^{51}$ Hoffman emphasized that admiralty courts "must be governed by equitable principles" and called them "the courts of chancery for the sea." ${ }^{.32}$ He repeatedly admonished lawyers who objected to the inelegant pleading of their adversaries that the "nice and technical rules" of common law did not hold sway in his admiralty court. ${ }^{53}$

Hoffman's response to one lawyer and friend, James T. Boyd, is instructive. Boyd had filed extensive exceptions to a libel on the grounds it failed to provide the full Christian names of the libellants. Hoffman admitted that under the "somewhat antiquated rules of the common law" a mistake in the Christian names, as opposed to surnames, constituted a fatal defect to a legal instrument. ${ }^{54}$ Nonetheless Boyd's citation of this distinction "tho perhaps of unimpeachable orthodoxy yet loses sight of the practical object intended to be obtained - viz the determination and identification of the party in the most certain manner." ${ }^{35}$ Thus while he might be bound to obey the literal terms of a statute, Hoffman rejected the dead hand of "antiquated" procedure while sitting in admiralty.

How Hoffman understood his obligations as California's federal admiralty judge not only governed procedure in his court but how he fashioned that court's jurisdiction. By definition the jurisdiction of federal admiralty courts contained both international and domestic aspects. In the case of foreign ships Hoffman exercised jurisdiction reluctantly, but did so whenever it appeared that failure to do so would leave the libellants remediless. Where resolution of a grievance might wait until the parties returned to their home port, Hoffman declined to accept jurisdiction. ${ }^{56}$ Thus, where the libellants were grossly maltreated Lascars (East Indian sailors), Hoffman consented to hear their case. ${ }^{57}$ In Fayet $v$. 


\section{Historical Society of Southern California}

The Ship "Henri," Hoffman assumed jurisdiction in a libel by French immigrants over the vigorous protest of their consul. ${ }^{\text {ss }}$ Hoffman preferred not to hear the case at all for he was neither "hungry after jurisdiction" nor "anxious to increase the already severe labors" of his office. ${ }^{59}$ In explaining why he assumed jurisdiction Hoffman touched upon concerns that guided him as a federal admiralty judge.

The court cannot be insensible to the particular circumstances which are directing a constant stream of immigration to this country. The eagerness felt by large classes in foreign countries to reap the golden reward that is supposed to await their labors here is well calculated to stimulate cupidity and produce abuses in passenger ships. Bound to a remote and perhaps in his opinion lawless country the master of such a vessel may permit infractions of his contract, or be guilty of abuses which he would hardly venture upon were he less secure of impunity. To say to all who have thus been injured that being foreigners justice is not for them and it must be sought in the country they have left perhaps forever, and at a distance of thousands of miles, is practically to deny it altogether and to establish a rule injurious to Commerce and inconsistent with sound policy. ${ }^{\mathrm{bo}}$

Ultimately Hoffman proclaimed "it my duty sitting in a national tribunal to administer justice to all who seek it except where controlling considerations call upon me to forbear." ${ }^{\text {"1 }}$

In the case of foreign ships "controlling considerations" consisted largely of the existence of an alternative forum. In domestic cases, however, congressional legislation and decisions of the United States Supreme Court acted as the restraints in Hoffman's effort to expand his jurisdiction. ${ }^{62}$ At times, as with the enforcement of state-created maritime liens, Hoffman stated his intention to assume such jurisdiction until reversed by a higher authority. When the High Court did begin to constrict federal admiralty jurisdiction in the late 1850s Hoffman dutifully complied. ${ }^{63}$

Notions of the equitable nature of this court underlay Hoffman's assumption of admiralty jurisdiction just as such considerations had affected pleading in that court. He expressed unwillingness to give relief to parties who appeared before him if they themselves were guilty of wrongdoing. ${ }^{64}$ Hoffman also showed his determination not to be influenced by "Lord Coke's bigotry" against non-common law courts or by the historical common law 


\section{California's Federal Admiralty Court}

fetters surrounding English admiralty courts. ${ }^{65}$ American admiralty judges, in Hoffman's view, were not bound by common law distinctions such as those between case and assumpsit. "Courts of admiralty administer justice ex acquo et bono and therefore are bound to take care that it shall not be obstructed in its course by a rigid adherence to technical rules." ${ }^{\prime \prime 6}$

The cases that best illustrate how Hoffman fashioned his jurisdiction in accord with his self-perception as a federal admiralty judge are those that dealt with breaches of passenger contracts. ${ }^{.7}$ Many of those who headed for California during the Gold Rush came on steamers via the Panamanian or Nicaraguan crossings. A dangerous and uncomfortable trip under the best of conditions, efforts by the steamship companies and other passenger carriers to maximize their profits often made a bad situation worse: The demand for passage led to terrible overcrowding and overbooking that sometimes left passengers stranded on the unhealthy isthmus.

Hoffman himself had made this trip at least three times and thus had personal knowledge of the conditions and possible abuses that passengers faced. The bulk of passenger cases alleged a breach of contract on the grounds of substandard accommodation and food or of being stranded. Conditions that forced 252 steerage passengers to share berths designed for 82 , forced passengers to sleep on open decks or in passage ways, forced 290 people to share two wash basins, or failure to provide minimal privacy and segregation of male and female passengers would simply "not be countenanced by the Court." In one sense such cases - as with complaints of stranding - were easily resolved under principles of maritime contract since the parties had explicitly agreed on the type of accommodation or the route to be travelled.

Initially, Hoffman determined breaches of contract based on the egregiousness of conditions; later, however, he attempted to establish standards of care that carriers owed to their passengers. In Harvey Sparks v. The Steamship "Sonora," Hoffman asked what kind of accommodation the owner of a passenger vessel must provide for a first class fare snd what amount of inconvenience that passenger should be expected to endure. ${ }^{\text {bn }}$ While he conceded that travel inevitably entailed some discomfort and inconvenience, Hoffman asserted that carriers had to maintain an objective standard of reasonable comfort. Pervasive overcrowding 


\section{Historical Society of Southern California}

and hardships "afford no justification for a continuance of the abuse - for the passenger contract must be construed to embrace a stipulation for such accommodations as are necessary to a reasonable degree of comfort - and to physical health and safety."”o Hoffman later extended his objective standard to all passengers, noting that while those traveling first, second, or steerage class could not expect similar comforts, they were entitled "to expect such accommodations and conveniences as the exercise of reasonable care, and the adoption of reasonable means for securing them by the owners can afford."

Beginning in 1858 Hoffman permitted the multiple joinder of passengers in suits against carriers for breach of contract. ${ }^{2}$ This procedural device became necessary because of "the great inconvenience and multiplication of costs which would result from compelling each passenger . . . to file his separate libel." ${ }^{\text {"73 }}$ Hoffman justified the novelty of his action by pointing out that seamen and materialmen were allowed to join in a single libel under certain circumstances and noted that in most cases unless passengers were allowed to join in one suit their legal costs would exceed their recovery. Hoffman also defended his approach from the objections of technical-minded pleaders and vowed to continue his practice until reversed by a higher authority. ${ }^{74}$

Hoffman became even bolder in providing relief for passengers who sustained tortious injury, whether physical or emotional. The novelty of these cases lay not in the fact that Hoffman granted relief but that he allowed the aggrieved parties to sue in rem as opposed to in personam, that is, he permitted the libellants to use the procedure unique to admiralty of suing a thing (i.e., the ship) rather than the person of the master or owner. In so doing Hoffman essentially converted tort actions into contract ones and provided the means of holding ship owners responsible for the negligence as well as the torts of their employees.

In 1852 Hoffman permitted a passenger who had been severely injured when he fell through a hatchway left open in an unlit part of a ship to sue in rem for the physical injuries and pain and suffering he experienced. ${ }^{75}$ While Hoffman declared it irrelevant whether the action was in tort or in contracts, he took pains to characterize the suit as a "breach of the contract to carry safely

- a promise implied by the law on the part of the carrier of 


\section{California's Federal Admiralty Court}

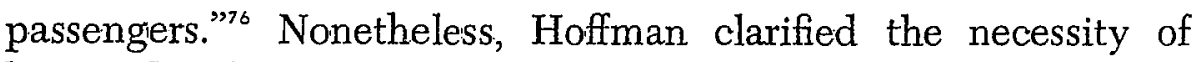
letting the libellant sue in rem.

Under the circumstances of this state it is of peculiar importance that passengers should have a prompt and effective remedy for breaches of contract entered into with them. The length of the voyage, the eagerness to reach California and the large profits derived from the transportation of passengers are well calculated to beget recklessness as to the mode of fulfilling passenger contracts; and were the passenger left to seek his remedy against an owner at the distance of thousands of miles or against a master without pecuniary responsibility it might open the door to grave if not dangerous abuses. ${ }^{77}$

In addition to medical expenses and loss of worktime, Hoffman awarded $\$ 3,000$ for pain and suffering. Following this reasoning Hoffman later permitted a passenger injured by the explosion of a boiler to sue the steamship. ${ }^{78}$

Hoffman not only offered relief for the negligent torts of the employees of passenger ships, but in one instance allowed an in rem suit for an intentional tort. The libellant, a passenger aboard the steamship "Golden Gate," had gotten into an argument with several of the ship's officers in the course of which he was hit over the head with a capstan bar, pummeled by the master, and then thrown down a hatchway. ${ }^{\circ}$ Even though the libellant may have been drunk and disorderly, Hoffman found the treatment inexcusable and clearly beyond the master's authority to maintain good order and discipline on board ship.

By authorizing an in rem suit, Hoffman circumvented a rule of the United States Supreme Court that actions for assault and battery in admiralty could only be brought in personam and rejected the argument that under the common law an employer had no liability for the intentional torts of his employee. ${ }^{80}$ Hoffman showed great determination to provide some practical relief for the passenger.

Hoffman's characterization of the cause of action viewed the allegation of the assault and battery "merely as a gravamen of the breach" of contract. ${ }^{81}$ As with the cases dealing with accommodation, Hoffman found an implied stipulation in passenger contracts. If denial of facilities, food, and the liberty of the deck constituted a breach, Hoffman asked, "is it less a breach if the 


\section{Historical Society of Southern California}

master deprives him of them by driving him from the table or deck by violence or insults, or wantonly and maliciously places him in confinement?" ${ }^{p 2}$ The implied stipulation in passenger contracts simply meant "that the authority given to the master and officers shall not be abused."

The same reason that justified the implied stipulation in passenger contracts - the absolute power a master wielded over his passengers - justified holding the owners liable for the master's and his officers' actions. By investing wide powers in their agents the owners were obligated "to treat passengers properly" and liable in rem for breaches of that duty. ${ }^{84}$ "To the passenger it affords the only substantial remedy - for a suit in personam against the master or the mates is in most cases fruitless." ${ }^{\text {ss }}$ Given contemporary travel "and particularly in California to and from which so great a stream of passengers is constantly pouring it seems to me of the utmost importance when their safety, their health, and their comfort depend so entirely upon the manner in which the carrier performs his contract, to hold any acts of his agent in the course of their duties, by which passengers are injured, substantial breaches of the contract and this whether the passenger be deprived of suitable food and accommodations or be subjected to ill usage by blows and false imprisonment or by habitual obscenity, insult and opposition." ${ }^{\text {" } 6 ~}$

Hoffman's reference to insults and obscenity referred to the emotional aspects of the implied stipulation of proper treatment of passengers. Beyond freedom from physical injury, passengers - particularly female ones - had the right to expect some regard for their "moral requirements." With respect to women these included "civility, decency, and exemption from brutal, cruel or obscene conduct." ${ }^{\circ 8}$ When a captain used language and acted in ways "grossly indecorous towards any female" or even behaved in a manner "calculated to shock the modesty and wound the susceptibilities of a virtuous woman," he and the owners of the ship were liable for mental distress. ${ }^{89}$ Hoffman justified imposing liability on the ship owners because contracts to convey passengers ought to receive different construction than "a contract to convey cattle."

Hoffman's concern that civilities be observed during voyages was not merely for the benefit of women. The judge displayed his 


\section{California's Federal Admiralty Court}

own sensibilities in his reluctance to discuss crude behavior or to hear testimony that cast aspersions on reputation, and in the outrage he showed at the suggestion that a married couple might be forced to share their private stateroom with a male stranger. ${ }^{91}$ To some extent Hoffman may have been fashioning requirements for cross-country travel that met his own standards of acceptability. It is tempting to speculate what effect Hoffman's judicial reputation had on his own voyages to and from New York.

On the other hand Hoffman saw himself as the only hope for many of the passengers who had suffered injuries during their voyages to San Francisco. Natural sympathy for their plight might have been enhanced by his belief that most of them were headed for disillusionment in seeking "to reap the golden reward that is supposed to await their labors here."192 Giving relief by allowing passengers to sue ships in rem helped, but did not end his duty as an admiralty judge. Exemplary damages in cases of flagrant abuses of passenger contracts provided yet another means of monitoring behavior on the high seas. In the face of profits to be made in transporting human cargo "it is only by the firm and constant enforcement by the courts of the rights of passengers that the repetition of abuses" against them "can be prevented.".93

In executing his role as California's federal admiralty judge, Hoffman exhibited moral courage as well as legal learning and ingenuity. In Martin Gallagher v. James Smith, Master of the Barque "Yankee," Hoffman heard a claim from a victim of San Francisco's notorious Vigilance Committee of $1856 .{ }^{94}$ Sentiment in favor of the Committee still ran high, and the legal record indicates that Gallagher brought his suit before Hoffman after it became clear that the state courts would not hear the claim. Gallagher, a night watchman at the Customs House, had been seized by the Committee and found guilty of ballot stuffing, riotous behavior, and of being a "disorderly character - a pest to society, and a nuisance." "s Sentenced to banishment and threatened with death if he ever returned to San Francisco, Gallagher was shipped to Hawaii on the Barque Yankee, in accordance with the Committee's so-called decree.

Hoffman determined that although his jurisdiction did not extend to Gallagher's seizure and confinement on land, it did embrace his transportation to and abandonment in Hawaii. No 


\section{Historical Society of Southern California}

question existed in Hoffman's mind as to his jurisdiction and duty in this case:

So long as our country remains under the dominion of law, and so long as the great constitutional provisions which secure the citizen his life, liberty, and property until deprived of them by due process of Jaw, are prized by the American people, and are enforced hy the courts; the deportation of a citizen to a foreign country, in an American ship, commanded by an American master in pursuance or execution of a sentence of an illegal and self-constituted body of men must remain a marine tort of the most flagrant description. ${ }^{2 n}$

Hoffman acknowledged that he could not redress the greatest injuries that Gallagher sustained, namely his seizure, disgrace, and damaged reputation. Nonetheless, over those acts within his jurisdiction, Hoffman intended to make an example by imposing exemplary damages of $\$ 3,000$ in addition to Gallagher's expenses. "It is of the first importance that masters and agents of ships should learn, that whatever be the power that in moments of popular excitement, illegal bodies of men may usurp . . . yet on Amcrican vessels on the High Seas the laws of the United States arc still supreme." "' Hoffman's decision may not have been very popular, but it certainly was in character.

Ogden Hoffman's admiralty opinions allow a tentative appraisal of his judicial style during the first quarter of his tenure as the Northern District's first judge. While taking into account the distinctive characteristics of admiralty, these early cases reveal. much both about Hoffman's judgeship and the nature of law in early California. Generalization about legal practice in California is appropriate since Hoffman's court did not have a distinct bar or exclusive jurisdiction over admiralty. ${ }^{98}$ Therefore the attorneys who appeared before Hoffman (and supplied much of the material and argument that fashioned his opinions) were undoubtedly practicing hefore state courts as well - perhaps even admiralty law.

The sheer diversity of sources - American, English, and Continental, not to mention the large collection of reports of federal decisions - provides abundant evidence that adjudication in Hoffman's court did not occur in primitive isolation. Moreover, the mannèr in which such materials were used suggests that not only 


\section{California’s Federal Admiralty Court}

Hoffman, but many of those who practiced in his court had been well trained as common lawyers and were far from parochial in their legal outlook. The sale of the law library of the leading San Francisco law firm of Halleck, Peachy, and Billings upon their dissolution in 1861 gives an idea of the level of legal sophistication of California's frontier law. Over 3,000 volumes were advertised for sale, far exceeding the range of materials cited by Hoffman during his first year as admiralty judge. ${ }^{99}$

Hoffman's legal education, awareness, and obedience to the dictates of the Supreme Court and Congress, and his idolization of Joseph Story made it unlikely that his court would ride roughshod over established legal traditions. Instead, Hoffman slowly readjusted his inherited legal values in the face of the peculiar setting of San Francisco and a growing appreciation that the weight of federal judicial authority rested primarily on his shoulders. As in his approach to the interpretation of ship's articles, Hoffman moved from a position of strict legal construction to a wider context informed by practicalities. Hoffman showed an increasing self-consciousness of the extent to which people depended upon him to provide a forum for their troubles. Particularly in admiralty - ostensibly the responsibility of the federal courts - Hoffman felt obligated to check single-handedly the abuses entailed in the massive passenger traffic to California. Acutely aware of the practical consequences of following strict distinctions between suits in rem and in personam, Hoffman bent legal rules while vowing to stop if ordered to do so by higher authorities. Thus, he provided immediate relief for libellants in his court, but acknowledged the limits of his judicial discretion.

Ultimately, the judicial style of Hoffman's early court consisted of a combination of his personality, social background, education, and experience as well as the conditions prevailing within the Northern District. Just as the personal characteristics of Hoffman gave a distinct form to his court, so too the pressing needs of libellants and Gold Rush California affected how Hoffman came to perceive his role as a federal judge. His sojourn in Paris, youth at appointment, and sensibilities as a gentleman help to explain his unusual reliance on French souroes, self-conscious erudition, and concern that ship passengers not be treated like cattle. Conversely, the distance of California from the "the states" and Hoff- 


\section{Historical Society of Southern California}

man's initial isolation as the only federal judge in San Francisco, perhaps explain why he deliberately expanded his jurisdiction and risked reprisal for condemning the activities of the Vigilance Committee.

While Hoffman's background and training were distinctive, there is no reason to impute atypicality to his experience as a federal judicial representative on the frontier. Beyond what they reveal about Hoffman as a judge, his admiralty opinions also shed light on the practice of law in early California. Far from being a primitive system even at its inception, the judicial style of Ogden Hoffman has suggested surprisingly sophisticated dimensions to law in the far west.

\section{NOTES}

The author would like to thank Chief United States District Judge Robert F. Peckham, Thomas G. Barnes, Joseph J. Franaszek, James H. Kettner, and Charles Royster for their helpful comments.

' Although Congress created two judicial districts for California in 1850, the overwhelming amount of judicial business fell to the Northern District. Apart from land cases, the Southern District faced a light case load (relative to the Northern District) especially during the first decade after statehood.

${ }^{2}$ For a shont sketch of Ogden Hoffman, Jr., see Oscar T. Shuck, History of the Bench and Bar of California (San Francisco, 1901), pp. 472-473. For Hoffman's father and grandfather, see the sketches by Richard B. Morris in the Dictionary of American Biography, Vol. 9.

3 Shuck, History of the Bench and Bar of California, p. 472.

4 In Memoriam Ogden Hoffman, Proceedings of the Bar Association of the City of San Francisco and in the Federal Courts (1891), p. 9.

5 Ibid.

- Ogden Hoffman, Jr., to F. H. Delano, May 28, 1850. Delano Family, Box 10, Franklin D. Roosevelt Library, Hyde Park, N.Y.

7 Ibid.

8 Ibid., July 31, 1850.

I Ibid.

10 Senate Executive Journal, Vol. 8: 281. In fact Hoffman was 'President Fillmore's third attempt to fill the Northern District judgeship. Fillmore had initially though the Senate confirmed Benjamin on September 28, 1840, he declined the appointment. Ibid., p. 267. Fillmore then nominated John Curry of California, but his confirmation floundered in the Senate in late January, 1851. Ibid., p. 286. For the background of Hoffman's appointment see Kermit L. Hall, "Mere Party and the Magic Mirror: California's First Lower Federal Judicial Appointments," Hastings Law Journal, XXXII (1981), 819-837.

11 Between May 19, 1851 and December 27, 1861, 1462 admiralty cases were filed by private individuals and the U.S. initiated 119 suits. Most (though not all) of Hoffman's admiralty opinions - as opposed to his decrees - have been pulled out of their case files and have been accessioned as Admiralty Opinions, Northern District of California, Record Group 21. 


\section{California’s Federal Admiralty Court}

Of the 150 collected opinions, only 19 were reported. Unless followed by a a citation to Federal Cases, all opinions cited are unreported.

12 See John T. Clauder et. al. v The Schooner "Eudorus," June 28, 1851; Daniel Dowl et. al. v. Schooner "J. B. Lippincott," July 2, 1851; John Carphin v. The Ship "Victoria," July 31, 1851; D. A. Shepherd v. I. Gardet and Co., August 28, 1851; L. Fayet et. al. v. The Ship "Henri," September 23, 1851; Taber et. al. v. The "Robert Browne," November 26, 1851; George Newell v. "The Steamship "Columbus," February 24, 1852; B. B. Williams v. The Steamship "Independence," March 2, 1852; E. Howland v. The Steamer "Quickstep," April 2, 1852; Charles Minturn v. The Ship "Hornet," November 30, 1852; J. F. Wendell v. Steamer "Martin White," February 13, 1856; Goddefroy, Sillem and Co. v. The "Live Yankee," February 18, 1857; Mason v. Barque "Chase," March 12, 1857; William Clark et. al. v. The Barque "Hyack," September 2, 1858; A. C. Hendley et. al. v. The Schooner "Lequellic," April 25, 1859, and J. B. Soulie et. al. v. The Barque "Pierre," March 5, 1861.

13 See C. M. Thompson v. Ship "Ionian," June 13, 1851; John T. Clauder et. al. v. The Schooner "Eudorus," June 28, 1851; Henry J. Dart v. The "Robert Hooper," July 9, 1851; Peter Flour v. The Barque "Pentucket," July 19, 1851; Herman Lower v. The Brig "Magdalena," July 19, 1851; Tyson v. The Cargo of the Ship "Orphan," July 21, 1851; Polack v. The Brig "Enterprise," July 27, 1851; John Carphin v. The Ship "Victoria," July 31, 1851; D. A. Shepherd v. I. Gardet and Co., August 28, 1851; Otis Webb et. al. v. Steamship "Antelope," September 22, 1851; L. Fayet et. al. v. The Ship "Henri," September 23, 1851; B. B. Williams v. The Steamship "Independence," March 2, 1852; Allen T. Wilson v. Henry A. Pierce, Fed. Cas. [17,826] March 24, 1852; Eugene Dupré v. The Steamer "North America," April 3, 1852; Stevens and Walker v. The Ship "Isaiah Crowell," September 2, 1853; J. W. Gill v. The Schoner "Fashion," February 12, 1856; J. F. Wendell v. Steamer "Martin White," February 13, 1856; United States v. The "E. Corning," January 30, 1857; Goddefroy, Sillem and Co. v. The "Live Yankee," February 18, 1857; William Clark et. al. v. The Barque "Hyack," September 2, 1858; W. H. Chamberlain et. al. v. The "Uncle Sam," March 9, 1859; Tully R. Wise v. The Schooner "Lequellic," July 6, 1859; J. B. Soulie et. al. v. The Barque "Pierre," March 5, 1861; and Crosby and Dibblee v. The Ship "Sunshine," her tackle, etc., December 3, 1861.

${ }^{14}$ See C. M. Thompson v. Ship "Ionian," June 13, 1851; John T. Clauder et. al. v. The Schooner "Eudorus," June 28, 1851; Robert Brown v. Ship "Clarendon," July 9, 1851; Tyson v. The Cargo of the Ship "Orphan," July 21, 1851; D. A. Shepherd v. I. Gardet and Co., August 28, 1851; L. Fayet et. al. v. The Ship "Henri," September 23, 1851; Bernard Curtis et. al. v. The Ship "Susan Drew," November 25, 1851; B. B. Williams v. The Steamship "Independence," March 2 , 1852; Allen T. Wilson v. Henry A. Pierce, Fed. Cas. [17,826] March 24, 1852 Robert Pinner v. The "Pacific," October 9 ,1852; Charles Minturn v. L. Maynard et. al., November 15, 1852; Henry W. Bennett v. Barque "Pathfinder" and James W. Hill, December 4, 1852; D. Nicholson, et. al. v. The "John Baring," March 23, 1853; George Helder v. The "Racehound," July 30, 1853; Steven and Walker v. The Ship "Isaiah Crowell," September 2, 1853; J. F. Wendell v. Steamer "Martin White," February 13, 1856; Thomas H. Place and James McGuire v. The Steamship "Golden Gate," Fed. Cas. [8,815] September 22, 1856; Hadgi Hassan v. The "Taitar," October 14 ,1856; William Humphrey v. The Ship "Mastiff," September 6, 1859; W. C. Anuan et. al v. The "Star of Hope," Fed. Cas. [405] November 11, 1859 and Chadwick et. al. v. The Ship "Gauntlett," August 31, 1861.

15 Allen T. Wilson v. Henry A. Pierce, Fed. Cas. [17,826] March 24, 1852.

16 United States District Court, Northern District of California, Admiralty Case Files, \#90, Libel of Allen T. Wilson.

17 Ibid.

18 Ibid. 


\section{Historical Society of Southern California}

19 Section 11 provides in part: "[N]o person shall be arrested in one district for trial in another, in any civil action, before a circuit or district court. And no civil suit shall be brought before either of said courts against an inhabitant of the United States, by any original process, in any other district than that whereof he is an inhabitant, or in which he shall be found at the time of serving the writ..." 1 U.S. Stat. 73 (September 24, 1789 ).

20 Wilson v. Pierce, Fed. Cas. [17,826] March 24, 1852.

21 Ibid.

22 Ibid.

${ }^{23}$ See Atkins v. The Disintegrating Company 85 U.S. 272 at 306 (1873).

24 For evidence of this trend in state courts see Lawrence M. Friedman, Robert A. Kagan, Bliss Cartwright and Stanton Wheeler, "State Supreme Courts: A Century of Style and Citation," Stanford Law Review, XXXIII (May 1981), 773-818.

${ }^{25}$ For Hoffman's references to his own cases see: Joseph Reynolds $v$. The Steamer "New World," April 17, 1852; Paul Berger v. The Ship "Defiance," March 22, 1853; Adrian and Story v. The "Live Yankee," Fed. Cas. [88] May 12, 1855; John W. Brittain v. The Ship "Alboni," Fed. Cas. [1,902] March 11, 1856; Charles Morrill v. The Ship "John Milton," February 24, 1858 and Bailey et. al. v. The "Sonora," Fed. Cas. [746] November 28, 1859.

For Hoffman's citations of California state court decisions - primarily the Supreme Court - see: Otis Webb et. al. v. Steamship "Antelope," September 22, 1851 ; United States v. The "E. Corning," January 30, 1857; Goddefroy, Sillem and Co. v. The "Live Yankee," February 18, 1857; J. C. Coghlin et. al. v. The Schooner Matilda Heron," September 9, 1857 and George Van Shultze v. C. Crafton, Master of the Schooner "San Diego," June 7, 1859.

26 See Herman Lower v. The Brig "Magdalena," July 19, 1851; John Carphin v. The Ship "Victoria," July 31, 1851; E. Howland v. The Steamer "Quickstep," April 2, 1852; Stevens and Walker v. The Ship "Isaiah Crowell," September 2, 1853; United States v. The Ship "Charlotte," September 26, 1853; J. W. Gill v. The Schooner "Fashion," February 12, 1856; Goddefroy, Sillem and Co. v. The "Live Yankee," February 18, 1857; Mason v. Barque "Chase," March 12, 1857; Tully R. Wise v. The Schooner "Lequellic," July 6, 18859 and J. B. Soulie et. al. v. The Barque "Pierre," March 5, 1861.

27 February 12, 1856.

28 Ogden Hoffman. Ir., to Ogden Hoffman, Sr., April 1, 1851, New York Historical Society, New York.

29 See the marginalia from Morris M. Estee, Hoffman's would-be editor and later Hawaii's first federal judge, in C. M. Thompson v. Ship “Ionian," June 13, 1851; Robert Brown v. Ship "Clarendon," July 9, 1851 and Santiago v. Morgan et. al. Fed. Cas. [12,331] July 9, 1851.

Hoffman's handwritten opinion in Thompson v. "Ionian" reveals the following marginalia from Estee: "Judge Hoffman - The facts in this case are not peculiar - nor are the points decided by you of any permanent interest - [except its] intrinsic interest. I would therefore beg to submit that it be left out."

30 See C. M. Thompson v. Ship "Ionian," June 13, 1851; Peter Flour v. The Barque "Pentucket," July 19, 1851; Ambrose P. Merrill v. The Barque "Peru," September 26, 1851; Bernard Curtis et. al. v. The Ship "Susan Drew," November 25, 1851; Taber et. al. v. The "Robert Broune," November 26, 1851; Joseph Reynold's v. The Steamer "New World," April 17, 1852; Charles Minturn v. The Ship "Hornet," November 30, 1852; G. W. Hudson et. al. v. The Ship "Severn," December 2, 1852; John W. Britton v. The Barque "Henelon," February 19, 1853; Thomas Shearon et. al. v. The Steamer "Pacific," June 15, 1853; George Helder v. The "Racehound," August 1, 1853; William James et. al. v. The Freight and part of the cargo of the Ship "Coronation," February 15, 1856; John W. Brittain v. The Ship "Alboni," Fed. Cas. [1,902] March 11, 1856; Farwell v. The "Harvey Buch," [N.D.] 1856; W. C. Annan et. al v. The "Star of Hope," November 


\section{California's Federal Admiralty Court}

11, 1859; Thomas Dooley et al. v. The Ship "Neptune's Car," September 12, 1860 and Williams et. al v. The "Storm King," January 3, 1861.

31 See C. M. Thompson v. Ship "Ionian," June 13, 1851.

32 See Saul Levy v. The "Caroline Reed," Fed. Cas. [8,301] December 31, 1852 and Adrian and Story v. The "Live Yankee," Fed. Cas. [88] May 12, 1855.

${ }^{33}$ See John W. Brittain v. The Ship "Alboni," Fed Cas. [1,902] March 11, 1856.

34 See W. C. Annan et. al. v. The "Star of Hope," Fed. Cas. [405] November $11,1859$.

${ }_{35}$ See Charles Peterson et. al. v. The "James C. Perkins," June 19, 1851.

36 Ibid.

37 See Thomas Smith et. al. v. The "Skylark," April 4, 1856 and Thomas Petre v. The "Horsburgh," December 20, 1858.

38 See Fed. Cas. [3,997] September 12, 1860.

39 Ibid.

40 Ibid.

41 C. M. Thompson v. Ship "Ionian," June 13, 1851.

42 Thomas Dooley et. al. v. The Ship "Neptune's Car," Fed. Cas. [3,992] September $12,1860$.

${ }^{43}$ See Williams et. al. v. The "Storm King," January 3, 1861.

44 Ibid.

45 See D. A. Shepherd v. I. Gardet and Co., August 28, 1851; Taber et. al. v. The "Robert Browne," November 26, 1851; Allen T. Wilson v. Henry A. Pierce Fed. Cas. [17,826] March 24, 1852; J. F. Wendell v. Steamer "Martin White," February 13, 1856 and John J. Fleming v. The proceeds of the Barque "Raymond," August 19, 1856.

46 See L. Fayet et. al. v. The Ship "Henri," September 23, 1851; Allen T. Wilson v. Henry A. Pierce Fed. Cas. [17,826] March 24, 1852; United States v. The Ship "Charlotte," September 26, 1853; United States v. Hoit et. al., March 22, 1854; Hadgi Hassan v. The "Taitar" October 14, 1856; William B. Downing et. al. v. The Schooner "Golden State," William S. Little and William Bell, September 17, 1858; Martin Gallagher v. The Barque "Yankee," and James Smith, Master of the "Yankee," January 17, 1859 and Medlin et. al. v. The Barque "Auckland," November 8, 1860.

47 United States v. Hoit, March 22, 1854.

48 Ibid.

49 Ibid.

so See C. M. Thompson v. Ship "Ionian," June 13, 1851; Santiago v. Morgan et. al. Fed. Cas. [12,331] July 9, 1851; Otis Webb et. al. v. Steamship "Antelope," September 22, 1851; Waring v. Hammond, March 27, 1854; Adrian and Story v. The "Live Yankee," Fed. Cas. [88] May 12, 1855; B. K. Horn v. Steamer "Martin White," November 30, 1855; A. J. Pope v. The Barque "Don Manual Ugarte," February 2, 1856; Josephine Gougenheim v. The Barque "Glimpse," February 5, 1859; and Benjamin Cohen v. Schooner "Lord Raglan," August 22, 1861.

51 See J. M. Middleton et. al. v. The Steamer "Gold Hunter," [N.D.] 1851; Eugene Dupré v. The Steamer "North America," April 3, 1852; A. Kreymel v. Alex Grogan and $N$. W. Lent, May 17, 1852; Stevens and Walker v. The Ship "Isaiah Crowell," September 2, 1853; John J. Fleming v. The proceeds of the Barque "Raymond," August 19, 1856; Farwell v. The "Harvey Buch," [N.D.] 1856; Nelson Pierce et. al. v. The Barque "Alberto," Fed. Cas. [11,142] September 3, 1857; O. P. West v. Steamship "Uncle Sam," February 9, 1858; Charles Hare v. The proceeds of the Schooner "Umpqua," May 6, 1858; William B. Downing et. al. v. The Schooner "Colden State," William S. Little and William Bell, September 17, 1858; Margaret Ferron v. The Barque "Emily Banning," December 29, 1858; John Norris and 220 others v. The Steamship "Sonora," January 24, 1859; W. H. Chamberlain et. al. v. The "Uncle Sam," March 9, 1859; Alfred 


\section{Historical Society of Southern California}

Moulin v. The "John L. Stephens," October 21, 1859 and W. H. Chamberlain et. al. v. The Steamship "Uncle Sam," November 15, 1859.

s2 Nelson Pierce et. al. v. The Barque "Alberto," Fed. Cas. [11,142] September 3,1857 .

${ }_{53}$ W. H. Chamberlain et. al. v. The "Uncle Sam," March 9, 1859.

54 lbid.

55 Ibid.

56 See John Carphin v. The Ship "Victoria," July 31, 1851 and Joseph Jackson et. al. v. The Brig "Decision," March 22, 1853.

57 See Hadgi Hassan v. The "Taitar," October 14, 1856.

58 September 23, 1851.

59 Ibid.

so Ibid.

o1 Ibid.

62 See D. A. Shepherd v. I. Gardet and Co., August 28, 1851; Allen T. Wilson v. Henry A. Pierce, Fed. Cas. [17,826], March 24, 1852; Eugene Dupré v. The Steamer "North America," April 3, 1852; G. W. Hudson et. al. v. The Ship "Severn," December 2, 1852; United States v. The "E. Corning," January 30, 1857; John Norris and 220 others v. The Steamship "Sonora," January 24, 1859; Scott D. A. Robison. v. The Steamship "Reytona," February 26, 1859; Scott and Curtis v. The "Morning Glory," Fed. Cas. [12,542] April 22, 1859; C. H. Harrison v. The Ship "Anna Kimball," Fed. Cas. [6,132] November 28, 1859.

o3 Scott and Curtis v. The "Morning Glory," Fed. Cas. [12,542] April 22, 1859.

64 William Moore et. al. v. The Ship "Roman," June 27, 1853.

6.5 See D. A. Shepherd v. I. Gardet and Co., August 28, 1851.

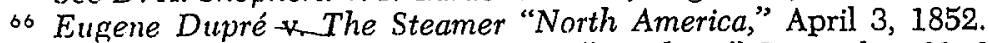

'7) See Otis Webb et. al. v. Steamship "Antelope," September 22, 1851; George Newell. v. The Steamship "Columbus," February 24, 1852; Eugene Dupré v. The Steamer "North America," April 3, 1852; Joseph Reynolds v. The Steamer "New World," April 17, 1852; Henry W. Bennett v. Barque "Pathfinder," and James W. Hill, December 4, 1852; D. Nicholson et. al. v. The "John Baring," March 23, 1853; Thomas Shearon et. al. v. The Steamer "Pacific," June 15, 1853; Jacob Burke v. The Steamer "Pacific," July 29, 1853; Thomas H. Place and James McGuire v. The Steamship "Golden Gate," September 22, 1856; B. T. Moses v. The "Cortes," December 26, 1857; O. P. West v. Steamship "Uncle Sam," February 9 , 1858; William. B. Douning et. al. v. The Schooner "Golden State," September 17, 1858; O. P. West v. The "Uncle Sam," Fed. Cas. [15,858] December. 15, 1858; Margaret Ferron v. The Barque "Emilyl Banning," December 29, 1858; John. Norris and 220 others v. The Steamship "Sonora," January 24, 1859; Josephine Gougenheim v. The Barque "Glimpse," February 5, 1859; W. H. Chamberlain et. al. v. The "Uncle Sam," March 9, 1859; Harvey Sparks v. The Steamship "Sonora," Fed. Cas. [13,212] June 28, 1859; William H. McDougal et. al. v. The "Grey Feather," July 12, 1859; W. H. Chamberlain et. al. v. Steamship "Uncle Sam," November 15, 1859; Bailey et. al. v. The "Sonora," Fed. Cas. [746] Novemher 28, 1859 and Robert F. Morrison and wife v. Steamer "John L. Stephens," Fed. Cas [9,847] April 2, 1861.

os William B. Downing et, al. v. The Schooner "Golden State," September 17, 1858.

69 Fed. Cas. [13,212] June 28, 1859.

70 Ibid.

7 Bailey et. al. v. The "Sonora," Fed. Cas. [746] November 28, 1959.

72 See Downing et. al. v. The Schooner "Golden State," September 17, 1858; John Norris and 220 others v. The Steamship "Sonora," January 24, 1859; William H. McDougal et. al. v. The "Grey Feather," July 12, 1859 and W. H. Chamberlain et. al. v. Steamship "Uncle Sam," November 15, 1859.

73 Downing et. al. v. The Schooner "Golden State," September 17, 1858.

74 John Norris and 220 others v. The Steamship "Sonora," January 24, 1859. 


\section{California's Federal Admiralty Court}

75 Eugene Dupré v. The Steamer "North America," April 3, 1852.

76 Ibid.

77 Ibid.

78 Joseph Reynolds v. The Steamer "New World," April 17, 1852.

79 Thomas H. Place and James McGuire v. The Steamship "Golden Gate," September 22, 1856.

80 The 16th practice rule in admiralty before the Supreme Court provided in part: "that in all suits for an assault and battery on the high seas, or elsewhere within the admiralty and maritime jurisdiction, the suit shall be in personam only." See McGuire et. al. v. The Golden Gate [Circuit Court, N.D. California, 1856] Fed. Cas. [8815] 142.

81 Ibid.

82 Ibid.

83 Ibid.

84 Ibid.

85 Ibid.

86 Ibid.

87 D. Nicholson et. al. v. The "John Baring," March 23, 1853.

8 Ibid.

so Henry W. Bennett v. Barque "Pathfinder" and James W. Hill, December 4, 1852.

90 D. Nicholson et. al. v. The "John Baring," March 23, 1853.

9 See Otis Webb et. al. v. Steamship "Antelope," September 22, 1851; Henry W. Bennett v. Barque "Pathfinder" and James W. Hill, December 4, 1852; Margaret Ferron v. The Barque "Emily Banning," December 29, 1858; Martin Gallagher v. James Smith, Master of the Barque "Yankee," Fed. Cas. [5,196] January 17, 1859; Bailey et. al. v. The "Sonora," Fed. Cas. [746] November 28, 1859, and Robert F. Morrison and wife v. Steamer "John L. Stephens," Fed. Cas. [9,847] April 2, 1861.

${ }_{92}$ L. Fayet et. al. v. The Ship "Henri," September 23, 1851.

93 Robert F. Morrison and wife v. Steamer "John L. Stephens," Fed. Cas. [9,847] April 2, 1861.

94 Fed. Cas. [5,196] January 17, 1859.

95 Ibid.

96 Ibid.

97 Ibid.

98 For a discussion of state court assumption of admiralty jurisdiction in California from 1850-1890, see Gordon M. Bakken, "Admiralty law in Nineteenthcentury California," Southern California Quarterly, LVIII (1976), 499-514.

99 "Catalogue of a valuable law library, containing three thousand volumes, being the entire law library of Messrs. Halleck, Peachy and Billings," April 22, 1861, Bancroft Library, University of Califormia, Berkeley. 